\title{
ON THE SECULAR VARIATION OF ICE FLOW VELOCITY AT LEWIS GLACIER, MOUNT KENYA, KENYA
}

\author{
By Stefan Hastenrath and Phillip Kruss \\ (Department of Meteorology, University of Wisconsin, Madison, Wisconsin 53706, U.S.A.)
}

\begin{abstract}
Measurements at various epochs in the course of the twentieth century indicate a slowing down of surface ice flow velocity. This is consistent with the numerical modeling of the secular glacier recession, which furthermore shows a gradual upward shift of the regions of highest velocity and mass flux. Crevasse orientation is transverse above, and longitudinal below, the velocity maximum. The secular change in the longitudinal velocity profile seems to affect the crevasse pattern. Net balance in the next five years is a major factor in future changes of the glacier. With this reservation, model calculations for a possible extreme scenario indicate a drastic overall velocity decrease, and a moderate further displacement of the velocity and mass-flux maxima up-glacier, by the mid 1980's.
\end{abstract}

RÉSUMÉ. Sur la variation seculaire de la vitesse de la glace au Lewis Glacier, Mount Kenya, Kenya. Des mesures à différentes époques au cours du vingtième siècle montrent un ralentissement de la vitesse superficielle de la glace. Ceci est cohérent avec la modélisation numérique de la régression séculaire du glacier qui, de plus, montre une remontée progressive en altitude des régions de plus forte vitesse et de plus gros bilans. L'orientation des crevasses est transversale au-dessus et longitudinale au-dessous du point de vitesse maximum. Le changement séculaire du profil de vitesse longitudinal semble affecter la disposition des crevasses. Le bilan glaciaire des cinq prochaines années est le facteur majeur des changements futurs du glacier. Sauf cette réserve, les calculs sur modèle pour un scénario extrême montrent une forte diminution globale de la vitesse, suivie d'un déplacement modéré vers le haut de la vitesse et des flux maximum de glace, vers le milieu des années 1980.

Zusammenfassung. Die säkularen Änderungen der Fliessgeschwindigkeit des Eises am Lewis Glacier, Mount Kenya, Kenia. Messungen zu verschiedenen Zeitpunkten im Laufe des zwanzigsten Jahrhunderts lassen eine Abnahme der Fliessgeschwindigkeit des Eises erkennen. Dies passt zur numerischen Modellrechnung des säkularen Gletscherrückgangs, die ausserdem auf eine allmähliche Verlagerung der Gebiete höchster Geschwindigkeit und Massenbewegung nach oben schliessen lassen. Die Orientierung der Spalten verläuft oberhalb des Geschwindigkeitsmaximums quer, unterhalb desselben jedoch parallel zur Fliessrichtung. Die säkulare Änderung im Geschwindigkeitslängsprofil scheint das Spaltenmuster zu beeinflussen. Die Nettobilanz der nächsten fünf Jahre wird ausschlaggebend für zukünftige Veränderungen des Gletschers sein. Mit dieser Einschränkung deuten Modellrechnungen unter extremen Annahmen auf eine drastische Abnahme der Gesamtgeschwindigkeit und eine weitere, mässige Verlagerung der Maxima von Geschwindigkeit und Massenfluss gletscheraufwärts um die Mitte der 80er-Jahre hin.

\section{INTRODUCTION}

A recent paper (Hastenrath and Kruss, [1981]) discussed the dynamics of the crevasse pattern at Lewis Glacier, Mount Kenya, where a monitoring program concerned with long-term glacier behavior and climatic change in the tropics is under way. Expanding on the earlier paper, field observations and computer simulation of ice dynamics are used here to gain insight into the secular variation of ice flow and crevasse patterns.

\section{Observations}

A summary of the field program in the course of the 1970's is updated from Hastenrath and Kruss ([1981]) in the next two paragraphs. 


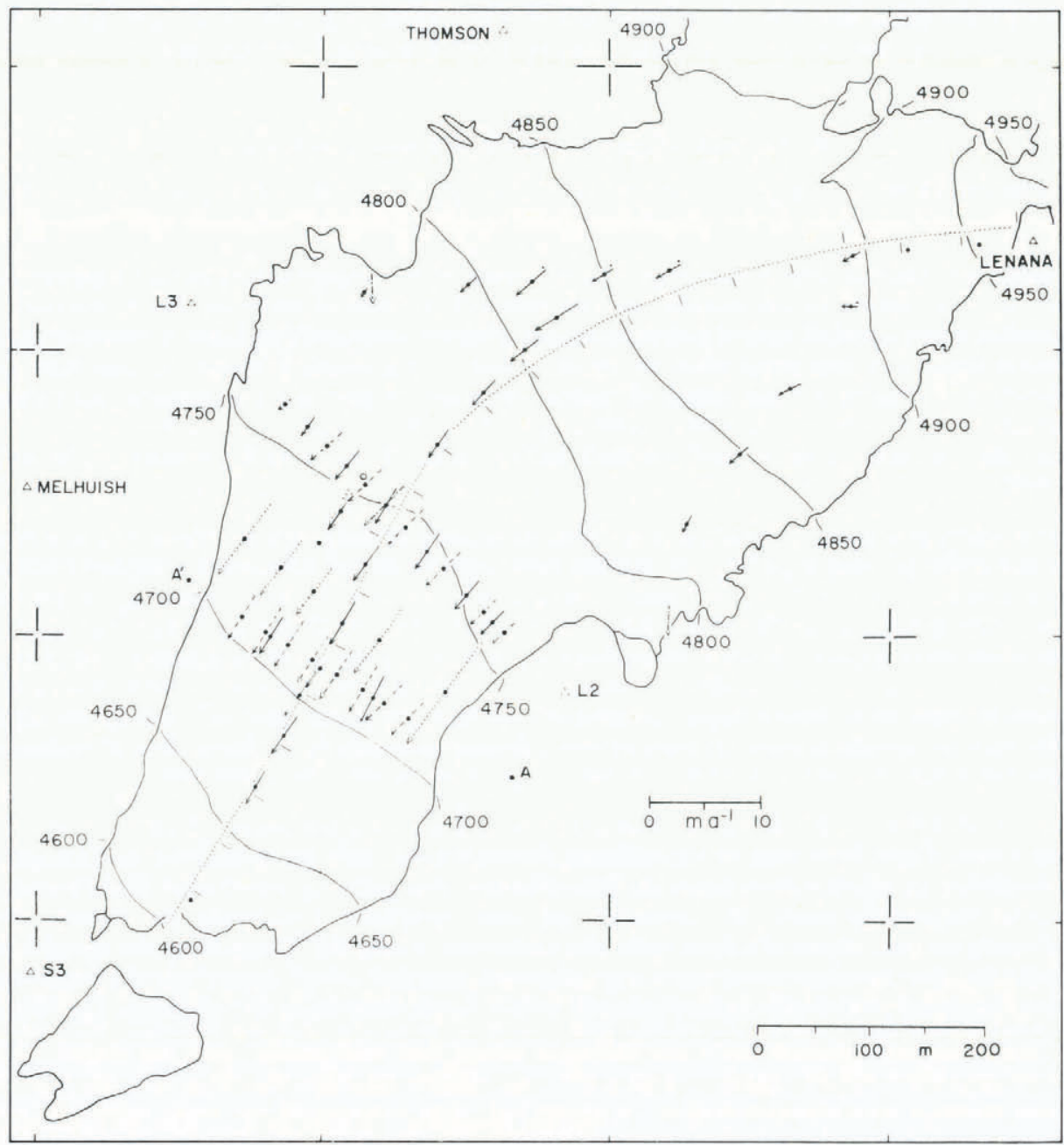

Fig. 1. Surface velocities measured at various epochs during the twentieth century. Dots indicate the location of targets, and arrows the direction and magnitude of motion. Dotted, dash-dotted, broken, and solid arrows refer to measurements in 1934 (Troll and Wien, 1949), in 1957 (Charnley, 1959), in 1973-74, and during 1978-80, respectively. Solid arrows with small dot at right-hand side of tail denote measurements limited to January-February 1978. Open circle, dot, and arrow with short tick marks along right-hand side of shaft refer to 1958 and 1974 positions and 16 year average displacement rate of the remnants of a meteorological shelter. The dotted line represents the modeled central line, with tick marks at $50 \mathrm{~m}$ intervals indicating longitudinal distance. 1978 height contours in meters are entered as thin solid lines. Points Thomson, Lenana, Melhuish, L.3, $L 2, S 3$ are control points outside the glacier. Scale 1:7 500. Velocity scale in $\mathrm{ma}^{-1}$ is ten times the horizontal scale (i.e. $10 \mathrm{~m} \mathrm{a}^{-1}$ would be represented as a $100 \mathrm{~m}$ arrow).

During a 1973/74 pilot project, a map at scale 1:2 500 was constructed from an aerial survey flown by the Kenya Air Force on 20 February 1974 (Caukwell and Hastenrath, 1977). This map can claim greater topographic detail than any previous chart (Troll and Wien, 1949; Charnley, 1959; Forschungsunternehmen Nepal Himalaya, 1967). Also as part of this project, 
ground survey and air photogrammetry were linked with a network of I.G.Y. control points on rock outcrops outside the glacier (Charnley, 1959), surface ice movement was monitored by repeatedly surveying the position of stakes laid out along two transects across the ice, and seismic profiles for determining ice thickness and measurements related to the mass budget were obtained.

As part of the December 1977-March 1978 field season, the Kenya Air Force repeated the aerial photogrammetric survey and a new map at scale 1:2 500 and with date of 13 February 1978 was constructed (Hastenrath and Caukwell, 1979). Further, an array of 31 stakes was placed on the glacier for measurements of net balance and surface ice movement, with electronic distance-measuring equipment allowing reliable displacement estimates over a time span as short as a few weeks. Ice thickness determination by the seismic and gravimetric techniques, heat and mass budget studies, and retrieval of ice cores were also tasks of this 1977/78 expedition. Seismic profiles, net-balance measurements, and re-surveys of motion stakes were the main objectives of the December 1978-January 1979 and December 1979-January 1980 expeditions.

Measurements of surface ice-flow velocity have been performed at various epochs during the twentieth century as summarized below.

The first surface velocity measurements on Lewis Glacier are due to Troll and Wien (1949) in May 1934. They laid out rocks in a straight line across the glacier, in the vicinity of the equilibrium line, and used terrestrial photogrammetry to determine the displacement over a $104 \mathrm{~h}$ interval.

The I.G.Y. Mount Kenya Expedition (Charnley, 1959) performed velocity measurements in various portions of the upper glacier by tacheometric surveys of stakes repeated over a period of about five months in 1957-58.

During a 1973-74 pilot project two lines of stakes were installed across the middle portion of the glacier and ice flow velocities were determined by tacheometric surveys repeated over periods of three and six months. Also at this time, the remnants of a meteorological shelter of the I.G.Y. expedition were located. With reference to the I.G.Y. map (Charnley, 1959), a displacement over a 16 year period could be determined.

During the December 1977-March 1978 expedition of the University of WisconsinMadison, an array of 31 stakes was installed on the glacier. Electronic distance measuring (EDM) equipment allowed reliable displacement estimates over a time span as short as a few weeks. The December 1978-January 1979 and December 1979-January 1980 expeditions included re-surveys of the motion stakes.

Results of the various aforementioned measurement programs are plotted in Figures 1 and 2 .

These velocity determinations are fraught with errors of differing magnitude, dependent on techniques and time interval. Uncertainties in the various measurements are estimated to be as follows: $3 \mathrm{~m} \mathrm{a}^{-1}$ for the 1934 photogrammetry; about $1 \mathrm{~m} \mathrm{a}^{-1}$ for the 1957 and 1973-74 tacheometric surveys; about $1.5 \mathrm{~m} \mathrm{a}^{-1}$ for the 1958-74 displacement estimate; and a few $\mathrm{cm} \mathrm{a}^{-1}$ for the 1978-80 EDM measurements (see Fig. 2). Note that the errors of the 1934 measurements are not only the largest but also the most difficult to estimate.

\section{NUMERICAL MODELING}

Reference is made to Hastenrath and Kruss ([1981]) for a description of the model of ice dynamics. In addition to the tasks performed in the earlier investigation, the model also permits 


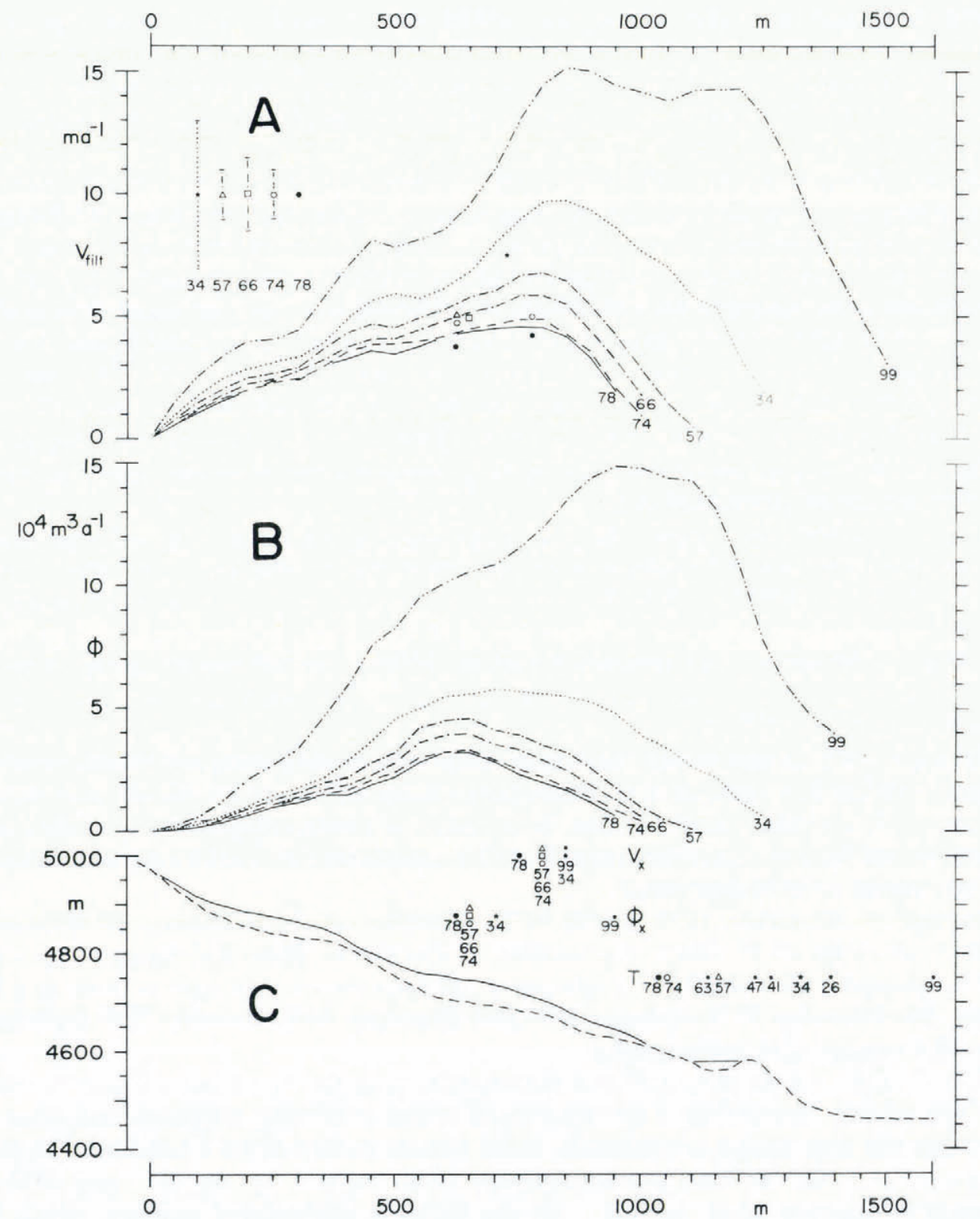

Fig. 2. Secular variation of surface velocity and mass flux along central line. Modeled longitudinal profiles are shown of (A) filtered velocity $V_{\text {filt }}$ and (B) mass flux $\phi$ for various epochs as follows: 1899 double dot-dashed, 1934 dotted, 1957 dash-dotted, 1966 double dash-dotted, 1974 broken, 1978 solid line. In the graph of $(A)$ of $V_{\text {fllt }}$, observed velocities are entered as asterisk for 1934, triangle for 1957, square for 1958 to 1974 mean displacement rate (labelled 1966), open circle for 1974, and large dot for 1978-80 (labelled 1978); vertical lines to the left indicate the estimated uncertainties of measurements. In the bottom part (C), bedrock topography is depicted as broken, and tarn and 1978 ice-surface topography by solid line. For the modeled maxima of surface velocity $V_{\mathrm{x}}$ and mass flux $\phi_{\mathrm{x}}$, and the observed terminus $T$, the positions since 1899 are entered in terms of down-glacier distance along the central line. 
calculation of the response of the ice mass to changes in net balance. In the present study, an initial input variation of net balance was modified by trial and error until a good fit between computed and observed glacier retreat was obtained. This basic approach was also employed by Allison and Kruss (1977). As well as glacier extent, longitudinal profiles of ice depth, surface velocity, and total mass flux are calculated. This allows an estimation of changes in these parameters with time.

\section{Secular variation of velocity pattern}

The earlier paper (Hastenrath and Kruss [1981]) contains maps of the surface velocity pattern during 1978-79 and of the flow-line pattern as constructed from the 1974 surface topography. As an update to the former map, Figure 1 shows surface velocities obtained from our measurements in the course of 1978-80. In addition, Figure 1 depicts the velocities measured at various earlier epochs in the course of this century; a good overall agreement of spatial pattern from the various surveys is seen. There is an indication of a gradual decrease of velocities with time.

Figure 2 depicts the mass flux and surface velocity along the longitudinal line identified in Figure 1 as obtained from numerical modelling for the epochs 1899, 1934, 1957, 1966, 1974, 1978. At various points along this central line, actual observations are entered for comparison. Uncertainties of measurements, as estimated in Section 2, are also shown. Where the location of survey targets was not close to the central line, values given were derived allowing for the systematic increase of velocities from the boundaries towards the middle of the glacier. Figure 2 indicates agreement between modeled and observed velocities within error tolerances. It furthermore illustrates the systematic tendencies for overall decrease of velocity and mass flux and upward displacement of maxima associated with the secular terminus retreat.

\section{Future glacier Behavior}

Given the drastic recession since the end of the last century, the future changes of Lewis Glacier are of considerable interest. These will depend on the climatic, and more specifically the net balance, conditions of the past, present, and near future. A computer simulation for the epoch 1985 was performed using as input the observed vertical net balance profile during the $1979 / 80$ budget year. This was a dry year with a negative net balance for all portions of the glacier, in contrast to the $1978 / 79$ balance year which approached equilibrium conditions. Modeling using the 1978-79 net balance produced the same general trends, albeit less pronounced. Thus the simulation represents a possible extreme scenario for the mid 1980's. Net balance is being monitored for the fourth consecutive budget year. Results are not displayed here because of space limitations. Strongly negative net balance over several years would entail a drastic thinning of the ice, although this circumstance is not explicitly considered in the computer simulation.

A drastic decrease of the velocity by 1985 was calculated. In fact, the computed glacier deteriorated to such an extent that the model began to break down, so that output is informative but not reliable. With reference to the 1978 datum, by the mid 1980's the maximum velocity decreased to less than half; the velocity maximum became flat and wandered some $100 \mathrm{~m}$ up the glacier; and the maximum mass flux decreased to much less than half, with its position moving less than $50 \mathrm{~m}$ up glacier. During this period, the terminus also receded about $50 \mathrm{~m}$. 
Concomitant with such a shift of the velocity maximum, one may expect some further upward displacement of the transition zone between longitudinal crevasses in the lower, and transverse crevasses in the upper glacier, but less well-defined contrasts in crevasse orientation than that detailed for the 1978 glacier in Hastenrath and Kruss ([1981]). Continued strongly negative net balance along with vanishing ice movement would set the stage for rapid overall thinning of ice, with terminus retreat becoming increasingly determined by the in situ net balance rather than the mass economy and flow dynamics of the glacier as a whole. The condition of the glacier in the mid 1980's is expected to lie between these model results and the observed 1978-80 conditions.

\section{Conclusions}

Measurements of surface velocities at various epochs in the course of this century bear out a slowing down of ice flow. Theoretical modeling shows this observed velocity decrease to be consistent with the well-documented secular glacier recession. The numerical simulation further suggests a marked decrease in the velocity maximum during the 1900 's and as well a gradual upward movement of the position of this maximum, which is associated with the change-over from predominantly transverse to longitudinal crevassing.

The rapid retreat of Lewis Glacier in recent times is illustrated by comparing the 1978 and 1974 aerial surveys (Caukwell and Hastenrath, 1977; Hastenrath and Caukwell, 1979; Hastenrath and Kruss, [1981]). Numerical modeling of the future behavior of Lewis Glacier indicates that it is likely that the glacier will continue to retreat at the present rate, or even more rapidly, into the mid 1980's. A major overall decrease in the surface velocity is also indicated, with the velocity by 1985 being reduced to an amount approaching half the 1978 value. Further, the computer simulation suggests that the velocity maximum will become less sharply defined and will move quite significantly up-glacier. An apparent manifestation of such a trend is the recent development of a large longitudinal crevasse reaching some $150 \mathrm{~m}$ into the region hitherto characterized by transverse crevasses. A continued tendency for such a changeover in the crevasse pattern merits attention in further surveys. Changes of Lewis Glacier up to 1985 depend on the past history and the net balance in the next five years. With this qualification, the model calculations indicate a plausible extreme scenario of velocity, mass flux, crevasse, and terminus conditions for the mid 1980's.

\section{ACKNOWLEDGEMENTS}

This study was supported through U.S. National Science Foundation Grants EAR77-13130 and EAR79-23897. The research is authorized by the Office of the President, Republic of Kenya.

MS. received 7 July 1981 and in revised form 14 September 1981

\section{REFERENCES}

Allison, I. F., and Kruss, P. 1977. Estimation of recent climate change in Irian Jaya by numerical modeling of its tropical glaciers. Artic and Alpine Research, Vol, 9, No. 1, p. 49-60. 
Caukwell, R A., and Hastenrath, S. 1977. A new map of Lewis Glacier, Mount Kenya. Erdkunde, Bd. 31, Ht. 2. p. 85-87.

Charnley, F. E. 1959. Some observations on the glaciers of Mt. Kenya. Journal of Glaciology, Vol. 3, No. 26. p. 480-92.

Hastenrath, S., and Caukwell, R. A. 1979. Variations of Lewis Glacier, Mount Kenya, 1974-78. Erdkunde, Bd. 33. Ht. 4, p. 292-97.

Hasienrath, S., and Kruss, P. [1981.] Dynamics of crevasse pattern at Lewis Glacier, Mount Kenya. Zeitschrift für Gletscherkunde und Glazialgeologie, Bd. 15, Ht. 2, 1979, p. 201-07.

Troll, C., and Wien, K. 1949. Der Lewisgletscher am Mount Kenya. Geografiska Annaler, Årg. 31, Ht. 1-4, p. 257-74. 